\title{
Pengaruh Pengetahuan, Kualitas Pelayanan, Produk, dan Religiusitas terhadap Minat Nasabah untuk Menggunakan Produk Simpanan pada Lembaga Keuangan Mikro Syariah
}

Abdul Haris Romdhoni, Dita Ratnasari

Sekolah Tinggi Ilmu Ekonomi AAS Surakarta, Indonesia

Email korenpondensi: harisromdhoni27@yahoo.com

\section{Recieved 28-06-2018 | Revised 08-07-2018 | Accepted 30-07-2018}

\begin{abstract}
This study aims to examine the influence of knowledge, service quality, product, and religiosity on customers' interest in using savings products at BMT Amanah Ummah Gumpang Kartasura, Sukoharjo. In this study for independent variables are knowledge, service quality, product, and religiosity, while for the dependent variable in this study is the interest of customers using deposit products. This study uses a sample of 100 people with sampling using a random sampling method. This study uses quantitative methods and primary data using a questionnaire that must be answered by the respondent. Data analysis in this study used Multiple Linear Regression. The results of this study can be concluded based on the t test, the variables of knowledge and religiosity have an influence on the interest of customers using savings products. While service and product quality variables do not have an influence on customer interest by using deposit products. Based on the F test shows that the knowledge, quality of service, products, and religiosity simultaneously influence the interest of customers to use savings products at BMT Amanah Ummah Gumpang Kartasura, Sukoharjo.
\end{abstract}

Keywords: Customer interest in saving, Knowledge, Service quality, Product, religiosity

Saran sitasi: Romdhoni, A., \& sari, D. (2018). Pengaruh Pengetahuan, Kualitas Pelayanan, Produk, dan Religiusitas terhadap Minat Nasabah untuk Menggunakan Produk Simpanan pada Lembaga Keuangan Mikro Syariah. Jurnal Ilmiah Ekonomi Islam, 4(02), 126-147. doi:http://dx.doi.org/10.29040/jiei.v4i02.307

DOI: :http://dx.doi.org/10.29040/jiei.v4i02.307

\section{Pendahuluan}

Lembaga keuangan memiliki peran penting bagi kehidupan suatu negara, terlebih pada negara yang sedang berkembang seperti negara Indonesia. Lembaga keuangan memiliki peran strategis yang disebabkan fungsi utama lembaga keuangan sebagai suatu lembaga yang berfungsi untuk mengumpulkan dana dari masyarakat dan menyalurkan dana ke masyarakat secara efektif dan efisien. Dengan peranan yang dimiliki tersebut, adanya lembaga keuangan diharapakan memberikan suatu kemanfaatan yang lebih bagi masyarakat, serta masyarakat diberikan kebebasan untuk memilih antara lembaga keuangan syariah dan lembaga keuangan non syariah. Pandangan masyarakat terhadap lembaga keuangan syariah di antaranya dapat mewakili dengan pandangan masyarakat secara umum terhadap lembaga keuangan syariah, yaitu (1) Tidak 
adanya bunga, (2) Lembaga keuangan syariah identik dengan sistem bagi hasil.

Namun demikian, ternyata persepsi dan sikap masyarakat terhadap bunga bank dan sistem bagi hasil sangat beragam. Sebagian masyarakat tetap menerima bunga, sebagiannya lagi menerima sistem bagi hasil. Sikap yang mencampur adukkan berbagai paradigma ini, memberi nuansa yang cukup menarik sebagai gambaran tentang pengetahuan, sikap, persepsi serta perilaku masyarakat dalam menyikapi kebijakan dual banking system tersebut. Lembaga keuangan syariah mengharamkan sistem bunga dan menghalalkan bagi hasil (Imran dan Hendrawan, 2017). Selain adanya beragam persepsi masyarakat mengenai lembaga keuangan syariah, adapun faktor yang mempengaruhi perkembangan lembaga keuangan syariah di Indonesia, yaitu rendahnya market share lembaga keuangan syariah di indonesia yang dipengaruhi oleh terbatasnya sumber daya modal dan jaringan yang dimiliki lembaga keuangan syariah. Sehingga lembaga keuangan syariah tidak mampu menjangkau dan melayani konsumen potensial di berbagai wilayah di Indonesia.

Faktor lain yang berpengaruh yaitu rendahnya pemahaman masyarakat tentang lembaga keuangan syariah, pemahaman masyarakat yang masih rendah tersebut disebabkan karena kurangnya pengetahuan mereka tentang ekonomi islam. Tidak semua umat muslim bisa memahami pentingnya ekonomi islam. Hal ini disebabkan karena kurangnya sosialisasi dari lembaga keuangan syariah tersebut dalam memberikan pemahaman tentang bahaya bunga (riba) bagi kehidupan kita dan kurangnya sosialisasi dalam memperkenalkan berbagai produk dan layanan yang ditawarkan pada nasabah, sehingga pengetahuan nasabah mengenai lembaga keuangan syariah masih kurang dan masyarakat pada umumnya masih menganggap bahwa sistem lembaga keuangan yang dijalankan oleh lembaga keuangan syariah tidak jauh berbeda dengan yang dijalankan oleh lembaga keuangan non syariah.
Dilihat dari rendahnya market share di Indonesia masih rendah dan belum mampu menjangkau dan melayani konsumen potensial di berbagai wilayah di indonesia. Oleh karena itu, didirikanlah suatu lembaga keuangan mikro syariah (BMT) yang dapat menjangkau dan melayani nasabah pada masyarakat menengah ke bawah, dengan munculnya lembaga keuangan mikro syariah ini akan memudahkan masyarakat di pedesaan dalam menggunakan jasa lembaga keuangan yang sesuai dengan prinsip syariah. Dalam konteks lembaga keuangan Syariah, BMT adalah suatu lembaga keuangan mikro syariah yang memiliki cara kerja yang hampir sama dengan lembaga keuangan syariah, namun yang membedakan terletak pada mekanisme operasionalnya (Ilmi, 2002).

Secara yuridis keberadaan BMT didasarkan pada Undang-Undang Republik Indonesia Nomor 17 Tahun 2012 tentang Perkoperasian dalam pasal 1 yang berbunyi "Koperasi adalah badan hukum yang didirikan oleh orang perseorangan atau badan hukum koperasi, dengan pemisahan kekayaan para anggotanya sebagai modal untuk menjalankan usaha, yang memenuhi aspirasi dan kebutuhan bersama di bidang ekonomi, sosial, dan budaya sesuai dengan nilai dan prinsip koperasi". Pada tanggal 25 September 2015, pemerintah menerbitkan Peraturan Menteri Koperasi dan Usaha Kecil Menengah Republik Indonesia Nomor 16/Per/M.KUKM/IX/2015 Tentang Pelaksanaan Kegiatan Usaha Simpan Pinjam dan Pembiayaan Syariah oleh Koperasi.

Baitul Maal wat Tamwil (BMT) ini memberikan suatu kemudahan bagi masyarakat di daerah pedesaan untuk menggunakan jasa lembaga keuangan yang menggunakan prinsip syariah, dimana tujuan utama dari BMT ini untuk meningkatkan pemberdayaan ekonomi pada masyarakat menengah ke bawah serta selain dalam melayani masyarakat di bidang keuangan, BMT juga terus meningkatkan kedekatan hubungannya dengan para anggota dan dilihat dari rendahnya pengetahuan masyarakat atau anggota tentang ekonomi islam tersebut, suatu 
BMT itu juga berperan dalam memberikan suatu pengetahuan atau pemahaman kepada para anggota mengenai sistem serta produk-produk yang digunakan dalam BMT agar para anggota lebih mengetahui, walaupun sebagian besar dari mereka belum paham dengan ekonomi islam.

Kualitas pelayanan merupakan salah satu faktor penting yang dapat mempengaruhi kepuasan dari para nasabah atau anggota. Kualitas merupakan suatu yang berhubungan dengan kondisi akan suatu produk, jasa, manusia, proses, dan lingkungan yang dapat memenuhi keinginan dan kebutuhan yang menimbulkan kepuasan pelanggan karena sesuai dengan harapan mereka (Sangadji, 2013). Kualitas jasa adalah ukuran seberapa baik tingkat pelayanan yang diberikan mampu sesuai dengan ekspektasi pelanggan (Tjiptono, 2000). Kualitas pelayanan yang baik sering dikatakan sebagai salah satu faktor penting dalam keberhasilan suatu bisnis. Kualitas pelayanan (service quality) dapat diukur dengan menggunakan lima dimensi (SERVQUAL). Dalam pandangan Islam yang dijadikan tolok ukur untuk menilai suatu kualitas pelayanan terhadap konsumen adalah standarisasi syariah. Oleh karena itu, BMT harus terus meningkatkan kinerjanya baik dalam meningkatkan kualitas pelayanan yang mencakup lima dimensi (SERVQUAL) dan keberagaman produk yang dimiliki agar dapat bersaing dengan lembaga keuangan syariah yang lainnya.

Produk adalah segala sesuatu yang berupa barang fisik, jasa, pengalaman, acara, orang, tempat, organisasi, informasi, dan ide yang ditawarkan pasar kepada pelanggan untuk memenuhi keinginan dan kebutuhan pelanggan (Kotler, 2018). Dalam pemasaran syariah, produk konsumen adalah suatu yang dapat berdaya guna, maupun materi yang dapat bermanfaat bila dikonsumsi, serta bernilai guna dalam menghasilkan suatu perbaikan material, moral, spiritual bagi konsumen (Hasan, 2012). Produk-produk yang ada dalam BMT menggunakan sistem nisbah atau presentase bagi hasil pada akad mudharabah yang pasti sesuai dengan prinsip syariah islam. Dengan nisbah bagi hasil yang tinggi masyarakat akan tertarik untuk menitipkan dananya pada bank dengan harapan mendapatkan imbalan yang diterima oleh kedua belah pihak bank maupun anggota (Anshori, 2018).

Selain dengan tingkat pengetahuan, kualitas pelayanan, dan produk, tingkat Religiusitas seseorang itu juga berpengaruh kuat bagi perilaku dari seseorang tersebut. Religiusitas adalah suatu tingkat dimana seseorang dapat komitmen atau setia kepada agamanya secara umum sudah diketahui bahwa agama dapat berpengaruh sangat kuat bagi seseorang (Safitri, 2017). Pengaruh tersebut akan terlihat pada identitas atau karakter diri dan nilai seseorang yang akhirnya akan berpengaruh terhadap cara seseorang dalam berkonsumsi. Begitu juga berhubungan dengan pengaruh seseorang itu untuk minat menggunakan jasa di suatu lembaga keuangan syariah atau mikro syariah, semakin tinggi religiusitas seseorang maka mereka akan lebih berhati-hati dalam mengambil suatu keputusan seperti halnya untuk menggunakan produk dari suatu lembaga keuangan khususnya syariah.

Minat adalah suatu kecenderungan untuk memberikan suatu perhatian dan bentindak untuk melakukan suatu aktivitas atau situasi yang menjadi obyek dari minat tersebut yang disertai dengan perasaan senang (Shaleh, 2008). Pada dasarnya jika seseorang tersebut mempunyai minat pada sesuatu, maka ia akan dapat menerima dengan baik dan bersikap positif dengan suatu obyek atau lingkungan yang menjadi obyek minatnya. Masyarakat menilai suatu lembaga keuangan itu tidak hanya terpaku pada masalah mengenai bunga bank, namun sudah mengalami suatu perkembangan pada persoalan kualitas, baik itu mengenai kualitas produk yang ditawarkan maupun kualitas pelayanan yang diberikan oleh lembaga keuangan tersebut. Jadi disini peran suatu lembaga keuangan mikro syariah (BMT) adalah untuk terus melakukan peningkatan dalam kualitas baik itu kualitas pelayanan yang diberikan maupun kualitas dan beragam produk yang ditawarkan dan pastinya produk-produk tersebut sesuai dengan prinsip 
syariah islam dengan tujuan agar dapat menarik minat nasabah untuk menggunakan produkproduk lembaga keuangan yang berdasarkan syariah islam.

Dari berbagai faktor tersebut penulis tertarik untuk melakukan suatu penelitian yang berhubungan dengan pengetahuan, kualitas pelayanan, produk, dan religiusitas apakah dari keempat faktor tersebut dapat mempengaruhi minat nasabah untuk tertarik menggunakan produk simpanan pada suatu lembaga keuangan mikro syariah di BMT Amanah Ummah Gumpang, Kartasura, Sukoharjo.

\section{Tinjauan Teori}

\subsection{Lembaga Keuangan Mikro Syariah}

Menurut UU No. 1 Tahun 2013 tentang Lembaga Keuangan Mikro (LKM). Pengertian Lembaga Keuangan Mikro (LKM) adalah lembaga keuangan yang melayani masyarakat secara khusus dalam skala mikro yang memberikan jasa dalam pengembangan jasa dan pemberdayaan masyarakat baik dalam melalui pinjaman atau pembiayaan, maupun pemberian jasa konsultasi dalam pengembangan usaha serta dalam melaksanakan pengelolaan simpanan, dalam suatu lembaga keuangan mikro pelaksanaan kegiatan usahanya tidak hanya untuk mendapatkan keuntungan saja. Lembaga keuangan mikro mempunyai asas, yaitu keadilan, kebersamaan, kemandirian, kemudahan, keterbukaan, pemerataan, berkelanjutan, kedayagunaan, dan kehasilgunaan.

\subsection{Baitul Maal wat Tamwil (BMT)}

Baitul Maal wat Tamwil (BMT) atau Balai Usaha Mandiri Terpadu adalah lembaga keuangan mikro yang dioperasikan berdasarkan prinsip syariah dengan menerapkan sistem bagi hasil dalam pembagian keuntungannya, menumbuhkembangkan derajat dan martabat serta membela kepentingan kaum fakir miskin, dan lembaga keuangan mikro syariah ini tumbuh dan diprakarsai dan modal awal berasal dari tokohtokoh masyarakat setempat dengan berlandaskan pada sistem ekonomi yang salaam (Hidayat, 2018). BMT sesuai dengan namanya mempunyai dua fungsi utama, yaitu:
1) Baitul Tamwil (rumah pengembangan harta), fungsi ini adalah untuk melakukan suatu pengembangan harta berupa pengembangan usaha-usaha produktif dan investasi dalam meningkatkan kualitas ekonomi pengusaha mikro dan kecil, antara lain dapat mendorong kegiatan untuk menabung dan menunjang pembiayaan untuk kegiatan ekonomi dengan menggunakan akad perjanjian yang sesuai dengan prinsip syariah seperti akad wadiah, mudharabah, dan musyarakah, murabahah dll.

2) Baitul Mal (rumah harta), dalam fungsi ini BMT melakukan kegiatannya dalam menerima zakat, infak, dan sedekah serta mendistribusikannya secara optimal sesuai dengan peraturan dan amanahnya.

\subsection{Pengetahuan}

Menurut Yasin, Zarlis \& Nasution, (2018), pengetahuan merupakan suatu ilmu atau pemahaman seseorang yang didapat setelah seseorang tersebut melakukan suatu penelitian terhadap objek tertentu. Definisi yang paling sederhana dari pengetahuan adalah kapasitas untuk melakukan tindakan. Jadi pengetahuan adalah berbagai informasi dan data yang telah kita ketahui kemudian setelah mengetahui tersebut kemudian muncullah berbagai pertanyaan untuk mengevaluasi kemampuan yang telah diperoleh.

Nasabah memiliki tingkatan pengetahuan produk yang berbeda, dalam pengetahuan ini dapat dipergunakan untuk menerjemahkan informasi baru, serta untuk menimbulkan suatu minat terhadap suatu produk dan membuat pilihan keputusan. Adapun pengetahuan dibagi menjadi empat jenis, yaitu: a) Pengetahuan atas produk; b) Pengetahuan jenis dan ragam produk; c) Pengetahuan tentang sistem yang digunakan dalam produk; d) Pengetahuan akan manfaat dari suatu produk (Susanti \& Marita, 2017).

Persaingan yang semakin meningkat dalam dunia lembaga keuangan mendorong lembaga keuangan untuk lebih berorientasi kepada konsumen atau nasabah. Diperlukan pengetahuan sebagai upaya untuk mendukung dalam memahami konsumen serta perilakunya. Pada 
dasarnya nasabah itu perlu memahami terlebih dahulu berbagai produk dalam lembaga keuangan agar tepat dalam melakukan pengambilan keputusan untuk memilih lembaga keuangan syariah sebagai pilihannya, baik itu dalam tingkat resiko yang akan dihadapi serta pihak lembaga keuangan harus transparan dalam menjelaskan setiap produk dan jasa yang ditawarkan kepada calon nasabah maupun nasabah lama.

\subsection{Kualitas Pelayanan}

Kualitas merupakan suatu yang berhubungan dengan kondisi akan suatu produk, jasa, manusia, proses, dan lingkungan yang dapat memenuhi keinginan dan kebutuhan yang menimbulkan kepuasan pelanggan karena sesuai dengan harapan mereka (Sangadji, 2013). Sedangkan menurut Putra, Handoyo \& Rochadi (2018), kualitas pelayanan dapat didefinisikan sebagai tingkat keunggulan sehingga, kualitas merupakan suatu unsur dari kebaikan.

Kualitas pelayanan (service quality) dapat diukur dengan menggunakan lima dimensi. Kelima dimensi tersebut menurut Lupiyoadi (2013), dimensi kualitas pelayanan (SERVQUAL) di bagi menjadi lima dimensi SERVEQUAL diantaranya adalah:

1) Berwujud (tangible) yaitu suatu kemampuan perusahaan dalam menunjukan eksistensi kinerjanya kepada pihak eksternal atau pelanggan.

2) Kehandalan (Reabilitiy) yaitu kemampuan perusahaan dalam memberikan suatu pelayanan kepada pelanggan sesuai dengan yang ditawarkan dan janjikan agar dapat memenuhi kepuasan pelanggan karena sesuai dengan harapan secara lebih akurat dan terpercaya.

3) Ketanggapan (responsiveness) yaitu suatu sikap respon atau kesigapan karyawan dalam memberikan bantuan kepada pelanggan serta memberikan pelayanan yang cepat, tepat, dan tanggap kepada pelanggan, yang meliputi kesigapan, kecepatan karyawan dalam mena- ngani transaksi serta penangan keluhan pelanggan.

4) Jaminan dan kepastian (assurance) yaitu suatu pengetahuan, kesopan santunan, keramahtamahan, perhatian dan kemampuan para pegawai perusahaan dalam memberikan pelayanan, ketrampilan dalam memberikan informasi dan kemampuan untuk menumbuhkan kepercayaan para pelanggan kepada perusahaan.

5) Empati (empathy) yaitu suatu bentuk pemberian perhatian yang tulus kepada para pelanggan yang bersifat individual atau pribadi dengan berupaya memahami keinginan dan harapan mereka.

Dalam suatu lembaga keuangan mikro syariah juga harus mengedepankan dalam peningkatan kualitas pelayanan kepada para nasabah karena dengan meningkatkan kualitas dari pelayanan akan berdampak pada terciptanya suatu kepuasan dan rasa nyaman dari para nasabah sehingga kebutuhan atau keinginan nasabah dapat terpenuhi dan sesuai dengan harapan mereka dan hal ini dapat memberikan suatu nilai tambah bagi lembaga keuangan mikro syariah tersebut agar dapat dipandang sebagai suatu lembaga yang professional dalam melayani segala kebutuhan nasabah secara cepat dan tepat.

\subsection{Produk}

Produk adalah segala sesuatu yang berupa barang fisik, jasa, pengalaman, acara, orang, tempat, organisasi, informasi, dan ide yang ditawarkan pasar kepada pelanggan untuk memenuhi keinginan dan kebutuhan pelanggan (Kotler, 2018). Menurut Amir (2005) dalam penelitiannya bahwa dalam karakteristik lembaga keuangan syariah berbeda dengan lembaga keuangan secara konvensional, dalam lembaga keuangan syariah produk-produknya adalah produk yang ditawarkan sesuai dengan prinsip syariah yang digunakan bukan hanya dipandang dari nama produknya tersebut.

Menurut Hasan (2012) dalam pemasaran syariah, produk konsumen adalah suatu yang dapat berdaya guna, maupun materi yang dapat 
bermanfaat bila dikonsumsi, serta bernilai guna dalam menghasilkan suatu perbaikan material, moral, spiritual bagi konsumen. Adapun indikator produk yang sesuai dengan prinsip syariah, yaitu: a) Menggunakan prinsip nisbah bagi hasil; b) Menghindari unsur riba; c) Menghindari unsur ketidakpastian (gharar); d) Menghindari unsur judi. Dalam lembaga keuangan mikro syariah juga harus meningkatkan kualitas dari produk yang ditawarkan tersebut karena dengan produk yang berkualitas maka kebutuhan nasabah akan produk tersebut akan terpenuhi dan sesuai dengan harapan nasabah serta yang pasti produk yang ditawarkan tersebut harus sesuai dengan prinsip-prinsip syariah dan terbebas dari unsur riba.

\subsection{Religiusitas}

Religiusitas adalah suatu tingkat dimana seseorang dapat komitmen atau setia kepada agamanya secara umum sudah diketahui bahwa agama dapat berpengaruh sangat kuat bagi seseorang (Lubis, 2017). Pengaruh tersebut akan terlihat pada identitas atau karakter diri dan nilai seseorang yang akhirnya akan berpengaruh terhadap cara seseorang dalam berkonsumsi. Lembaga keuangan mikro syariah atau BMT yang berlandaskan syariah, maka dalam religiusitas itu harus diwujudkan dalam berbagai sisi ketaatan terhadap agama yang dianut dan diaplikasikan dalam menjalani kehidupan. Agama merupakan suatu sistem dari simbol, keyakinan, nilai, dan perilaku dari seseorang yang terlembagakan, yang berpusat pada pengahyatan terhadap persoalan yang paling maknawi (ultimate meaning) (Djamaludin \& Suroso, 2011).

Terdapat lima dimensi dalam religiusitas (Djamaludin \& Suroso, 2011), yaitu:

1. Dimensi keyakinan adalah suatu tingkatan dimana seseorang dapat menerima sejauh mana hal-hal yang dogmatik (kepercayaan yang tidak boleh dipersoalkan/harus diterima sebagai kebenaran) dalam agamanya, missalnya keyakinan kepada Tuhan, malaikat, surga dan neraka. Pada dasarnya setiap agama menginginkan adanya suatu keyakinan atau kepercayaan serta ketaatan bagi setiap pengikutnya.

2. Dimensi praktik agama adalah suatu tingkatan sejauh mana seseorang dapat menjalankan kewajiban-kewajiban ritual dalam agamanya. Dalam agama islam bentuk dimensi praktek dapat dilakukan dengan ibadah shalat, puasa, zakat, haji ataupun praktek muamalah lainnya.

3. Dimensi pengalaman adalah suatu perasaanperasaan atau pengalaman yang telah dialami dan dirasakan oleh seseorang. Misalnya, perasaan kita selalu dekat dengan Tuhan, perasaan takut dan gelisah apabila kita melakukan dosa, selalu merasa doanya dikabulkan, merasa selalu diselamatkan oleh Tuhan, dan sebagainya.

4. Dimensi pengetahuan agama adalah suatu dimensi yang menerangkan seberapa jauh seseorang telah memahami dan mengetahui tentang ajaran-ajaran agamanya, terutama yang ada di dalam kitab suci manapun yang lainnya.

5. Dimensi Pengamalan adalah suatu dimensi yang mengukur sejauh mana perilaku seseorang yang termotivasi oleh ajaran ajaran agamanya dalam kehidupan sosial. Misalnya menjalankan syariat agama islam dengan baik dan benar, menjenguk tetangganya yang sakit, menolong orang yang kesulitan, mendermakan hartanya, dan sebagainya.

\subsection{Minat}

Minat adalah suatu kecenderungan untuk memberikan suatu perhatian dan bentindak untuk melakukan suatu aktivitas atau situasi yang menjadi obyek dari minat tersebut yang disertai dengan perasaan senang (Shaleh, 2008). Pada dasarnya jika seseorang tersebut mempunyai minat pada sesuatu, maka ia akan dapat menerima dengan baik dan bersikap positif dengan suatu obyek atau lingkungan yang menjadi obyek minatnya. Lembaga keuangan mikro syariah memberikan suatu rangsangan kepada masyarakat untuk menarik minatnya dalam menabung, namun rangsangan tersebut hanya terbatas pada hasil yang dapat dirasakan oleh nasabah secara langsung. Nasabah saat ini akan lebih berhati- 
hati dalam mengambil suatu keputusan untuk menggunakan berbagai produk yang ditawarkan oleh suatu lembaga keuangan yang akan dipilihnya sebagai tempat untuk menginvestasikan dananya.

Faktor yang mempengaruhi timbulnya minat, yaitu: a) Faktor dari dorongan dari dalam individu; b) Faktor motif sosial; c) Faktor emosional atau perasaan; d) Daya Tarik Produksi (Sukron, 2012). Kemudian ada beberapa karakteristik nasabah yang dapat dijadikan indikator bahwa nasabah tersebut memiliki minat yang tinggi terhadap lembaga keuangan mikro syariah, yaitu (Hurriyati, 2010): 1) Senantiasa melakukan pembelian ulang secara teratur; 2) Merekomendasikan produk-produk lembaga keuangan mikro syariah kepada orang lain; 3) Tetap bertahan menjadi nasabah lembaga keuangan mikro syariah dan tidak mudah terpengaruh oleh produk sejenis yang ditawarkan oleh pesaing.

\section{Metode Penelitian}

Penelitian ini dilakukan di Baitul Maal Wat Tamwil (BMT) Amanah Ummah Gumpang Kartasura, Sukoharjo. Penelitian ini menggunakan metode penelitian deskriptif dengan pendekatan analisis kuantitatif, yaitu yaitu analisis yang bertujuan mengubah kumpulan data mentah menjadi mudah dipahami dalam bentuk informasi yang lebih ringkas (Sugiyono, 2010). Dan alat ukur yang digunakan dalam penelitian ini adalah menggunakan skala likert. Skala ini meminta responden untuk menunjukkan tingkat persetujuannya terhadap serangkaian pernyataan tentang suatu obyek. Skala likert banyak dijumpai dalam riset-riset pemasaran yang menggunakan metode survey dan dapat dikategorikan sebagai skala interval (Sugiyono, 2010).

Dalam penelitian ini metode deskriptif kuantitatif digunakan untuk mengkaji dan mengukur nilai rata-rata dari variabel pengetahuan, kualitas pelayanan, produk, dan religiusitas terhadap minat menggunakan produk simpanan pada lembaga keuangan mikro syariah. Untuk mengukurnya dilakukan dengan cara menyebar angket serta memberi skor dengan menggunakan skala likert, dengan jawaban angket yang diisi oleh anggota BMT Amanah Ummah Gumpang Kartasura, Sukoharjo.

Populasi dalam penelitian ini adalah 8954 anggota simpanan mudharabah BMT Amanah Ummah Gumpang Kartasura, Sukoharjo. Penentuan sampel dalam penelitian ini menggunakan rumus Slovin dengan presentase kelonggaran ketidak telitian karena kesalahan pengambilan sampel yang masih di tolerir 10\%. Dari hasil perhitungan dengan menggunakan rumus slovin tersebut diperoleh hasil sebanyak 100. Maka jumlah sampel yang akan diteliti sebanyak 100 anggota di BMT Amanah Ummah Gumpang Kartasura, Sukoharjo. Teknik pengambilan sampel dalam penelitian ini adalah dengan teknik random sampling.

\section{Teknik Analisis}

Adapun teknis analisis data dalam penelitian ini menggunakan analisis regresi berganda yaitu suatu alat analisis peramalan nilai pengaruh dua variabel bebas atau lebih terhadap variabel terikat untuk membuktikan ada atau tidaknya hubungan fungsi atau hubungan kausal antara dua variabel bebas atau lebih dengan satu variabel terikat (Algifari, 2013). Persamaan regresi yang dirumuskan berdasarkan hipotesis yang dikembangkan adalah sebagai berikut:

$$
Y=\alpha+\beta_{1} X 1+\beta_{2} X 2+\beta_{3} X 3+\beta_{4} X 4+e
$$

Keterangan:

$\mathrm{Y}=$ minat nasabah menggunakan produk

simpanan mudharabah

$\alpha=$ Konstanta

$$
\boldsymbol{\beta}_{1}-\boldsymbol{\beta}_{4}=\text { koefisien regresi }
$$

$\mathrm{X}_{1}=$ Pengetahuan

$\mathrm{X}_{2}=$ Kualitas Pelayanan

$\mathrm{X}_{3}=$ Produk

$\mathrm{X}_{4}=$ Religiusitas

$\mathrm{e}=$ eror

Untuk mendapatkan model regresi yang baik harus terbebas dari penyimpangan data yang terdiri dari multikolinieritas, heteroskedastisitas dan normalitas. Cara yang digunakan untuk menguji penyimpangan asumsi klasik adalah sebagai berikut (Ghozali, 2011) 
1. Uji Multikolinearitas, artinya antar variabel independen yang terdapat dalam model regresi memiliki hubungan linier yang sempurna atau mendekati sempurna (koefisien korelasinya tinggi atau bahkan satu). Cara mengetahui multikolinearitas adalah dapat dilihat dari nilai Tolerance dan VIF pada table Coeffisien. Jika nilai tolerance $>0,1$ dan nilai VIF < 10 maka dapat dikatakan tidak ada multikolinearitas antar variabel independen.

2. Uji Heteroskedastisitas, adalah varian residual yang tidak sama pada semua pengamatan di dalam model regresi. Untuk mengetahui ada atau tidaknya heteroskedastisitas pada suatu model dapat dilihat dari pola gambar scatterplot model. Dengan dasar penentuan jika model tersebut tidak terdapat heteroskedastisitas apabila (Prasetyo, 2017): Penyebaran titik-titik data sebaiknya tidak berpola; Titik-titik data menyebar diatas dan dibawah atau disekitar angka 0; Titik data tidak mengumpul hanya diatas atau dibawah saja.

3. Uji Normalitas, suatu uji dalam model regresi apakah dalam pengujian tersebut, variabel pengganggu atau residual memiliki distribusi normal (Ghozali, 2011). Suatu regresi yang baik yaitu memiliki distribusi data normal atau mendekati normal. Pengujian normalitas dapat dilihat dari nilai Asymp Sig. Dalam hasil uji normalitas ini menggunakan one simple Kolmogorov-smirnov Test. Jika model regresi tersebut berdistribusi secara normal maka Probability dari Kolmogorov-smirnov lebih besar dari 0,05 ( $p>0,05)$.

4. Uji Autokolerasi, sebuah pengujian yang bertujuan untuk menguji apakah didalam model regresi terdapat antara kesalahan penganggu (residual) pada periode tertentu dengan kesalahan pengganggu pada periode sebelumnya. Deteksi adanya suatu autokorelasi dengan menggunakan tabel DurbinWatson, dimana jika DW diantara -2 sampai +2 berarti tidak ada autokorelasi, jika angka D-W dibawah -2 maka terjadi autokorelasi positif, dan jika angka D-W diatas +2 maka terjadi autokorelasi namun negatif (Santoso, 2001).

\section{Hasil dan Pembahasan}

\subsection{Uji Asumsi Klasik}

Tabel 1. Uji Multikolinearitas

\begin{tabular}{ccc}
\hline Variabel & Tolerance & VIF \\
\hline Pengetahuan & 0,433 & 2,311 \\
Kualitas Pelayanan & 0,581 & 1,720 \\
Produk & 0,416 & 2,406 \\
Religiusitas & 0,876 & 1,141 \\
\hline
\end{tabular}

Keterangan: * tidak ada masalah multikolinearitas

Tabel 2. Uji Normalitas

\begin{tabular}{cccc}
\hline $\begin{array}{c}\text { Test } \\
\text { Statistic }\end{array}$ & $\begin{array}{c}\text { Asymp. } \\
\text { Sig. }\end{array}$ & Keterangan \\
\hline 0,078 & 0,140 & Data normal \\
\hline \multicolumn{4}{c}{ Tabel 3. Uji Autokolerasi } \\
\hline Model & Durbin-Watson & DU & 4-DU \\
\hline 1 & $2,045^{*}$ & 1.758 & 2,242 \\
\hline
\end{tabular}

Keterangan: * tidak ada masalah Autokorelasi

Gambar 4. Heteroskedastisitas

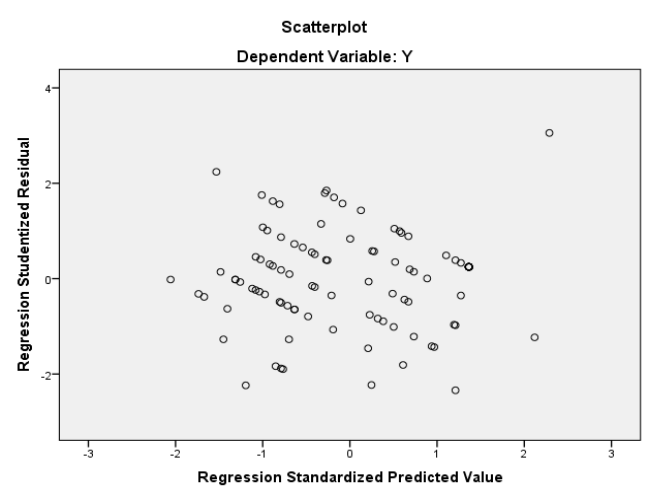

\subsection{Analisis Regresi Linear Berganda}

Adapun hasil uji regresi linear berganda menggunakan program SPSS 23 adalah sebagai berikut:

Tabel 5. Hasil Uji Regresi Linear Berganda

\begin{tabular}{|c|c|c|c|c|}
\hline Model & Koef & $\begin{array}{c}\text { Std. } \\
\text { Error }\end{array}$ & $\begin{array}{c}\mathrm{t} \\
\text { hitung }\end{array}$ & Sig. \\
\hline (Constant) & 0,440 & 2,614 & 0,168 & 0,867 \\
\hline Pengetahuan & 0,315 & 0,104 & 3,034 & $0,003 *$ \\
\hline $\begin{array}{l}\text { Kualitas } \\
\text { Pelayanan }\end{array}$ & 0,123 & 0,095 & 1,295 & $0,19 \$$ \\
\hline Produk & 0,206 & 0,118 & 1,754 & 0,083 \\
\hline Religiusitas & 0,228 & 0,109 & 2,093 & $0,039 * *$ \\
\hline $\mathrm{F}_{\text {hitung }}$ & $20,361 *$ & & & \\
\hline R Square & 0,462 & & & \\
\hline
\end{tabular}


Berdasarkan hasil regresi linear berganda yang diteliti pada variabel Pengetahuan $\left(\mathrm{X}_{1}\right)$, Kualitas Pelayanan $\left(\mathrm{X}_{2}\right)$, Produk $\left(\mathrm{X}_{3}\right)$, dan Religiusitas $\left(\mathrm{X}_{4}\right)$ terhadap Minat Nasabah (Y) dapat digambarkan sebagai berikut:

$$
Y=\underset{0,228 X_{4}}{0,440}+0,315 X_{1}+0,123 X_{2}+0,206 X_{3}+
$$

\subsection{Pengaruh pengetahuan terhadap minat nasabah.}

Hasil penelitian menunjukkan bahwa terdapat pengaruh yang signifikan antara variabel pengetahuan terhadap minat nasabah menggunakan produk simpanan di BMT Amanah Ummah Gumpang dengan signifikansi yaitu $0,003<0,05$ sehingga dapat disimpulkan bahwa $\mathrm{H}_{0}$ ditolak dan $\mathrm{H}_{1}$ diterima yaitu terdapat pengaruh yang signifikan antara pengetahuan terhadap minat nasabah menggunakan produk simpanan di BMT Amanah Ummah Gumpang dengan nilai koefisien pengaruh sebesar 0,315.

Berdasarkan hasil penelitian tersebut dapat disimpulkan bahwa pengetahuan nasabah dapat mempengaruhi minat mereka dalam menggunakan produk simpanan di BMT Amanah Ummah Gumpang, bagi BMT Amanah Ummah Gumpang dengan memberikan pengetahuan kepada masyarakat akan produk-produk yang dimiliki oleh BMT Amanah Ummah Gumpang merupakan hal yang sangat penting karena dengan memberikan pengetahuan atau pemahaman kepada masyarakat mengenai produk-produk dalam BMT Amanah Ummah Gumpang, maka akan meningkatkan pemahaman mereka serta dapat mendorong minat mereka untuk menggunakan jasa yang ditawarkan oleh BMT Amanah Ummah Gumpang.

Hasil penelitian ini konsisten dengan penelitian sebelumnya yang dilakukan oleh Susanti \& Marita (2017), Pengaruh Pengetahuan, Lokasi, Kualitas Pelayanan, Dan Bagi Hasil Terhadap Keputusan Anggota Menabung Di BMT Umat Sejahtera Kalijambe. Hasil ini menunjukkan bahwa keputusan anggota untuk menabung di BMT Umat Sejahtera Kalijambe dipengaruhi oleh variabel pengetahuan, variabel lokasi, variabel kualitas pelayanan, dan variabel bagi hasil.

\subsection{Pengaruh kualitas pelayanan terhadap minat nasabah.}

Hasil penelitian menunjukkan bahwa tidak terdapat pengaruh yang signifikan antara variabel kualitas pelayanan terhadap minat nasabah menggunakan produk simpanan di BMT Amanah Ummah Gumpang dengan signifikansi yaitu $0,198>0,05$ sehingga dapat disimpulkan bahwa $\mathrm{H}_{0}$ diterima dan $\mathrm{H}_{2}$ ditolak yaitu tidak terdapat pengaruh yang signifikan antara kualitas pelayanan terhadap minat nasabah menggunakan produk simpanan di BMT Amanah Ummah Gumpang dengan nilai koefisien pengaruh sebesar 0,123 .

Berdasarkan hasil penelitian diatas dapat disimpulkan bahwa minat nasabah untuk menggunakan produk simpanan di BMT Amanah Ummah Gumpang sangat kecil dipengaruhi oleh dimensi kualitas pelayanan. Pengaruh dimensi kualitas pelayanan terhadap minat nasabah untuk menggunakan produk simpanan yang tidak signifikan menandakan bahwa nasabah di BMT Amanah Ummah Gumpang hanya sedikit yang menggunakan dimensi kualitas pelayanan sebagai pengukur atau landasan untuk minat dalam menggunakan produk simpanan di BMT Amanah Ummah Gumpang.

Dalam penelitian Pratiwi (2016), menyatakan bahwa kualitas pelayanan memiliki pengaruh secara tidak langsung terhadap minat beli ulang melainkan memiliki pengaruh terhadap kepuasan pelanggan. Kualitas pelayanan merupakan salah satu faktor yang berperan dalam membangun kepuasan pada pelanggan dan dijadikan sebagai penilaian akhir seseorang yang mempengaruhi minat pelanggan dalam memutuskan minat beli ulang.

Hasil penelitian ini konsisten dengan penelitian sebelumnya yang dilakukan oleh Yuanita (2017), Pengaruh Produk, Kualitas jasa, Promosi, dan Lokasi Terhadap Keputusan nasabah penabung di BMT Mandiri Sejahtera Cabang Pasar Kranji, Lamongan Jawa Timur. Hasil ini menunjukkan bahwa tidak terdapat pengaruh secara signifikan dari variabel produk, kualitas jasa, promosi terhadap keputusan nasabah penabung 
di BMT Mandiri Sejahtera Cabang Pasar Kranji, Lamongan Jawa Timur, sedangkan variabel lokasi terdapat pengaruh secara signifikan terhadap keputusan nasabah penabung di BMT Mandiri Sejahtera Cabang Pasar Kranji, Lamongan Jawa Timur.

\subsection{Pengaruh produk terhadap minat nasabah.}

Hasil penelitian menunjukkan bahwa tidak terdapat pengaruh yang signifikan antara variabel produk terhadap minat nasabah menggunakan produk simpanan di BMT Amanah Ummah Gumpang dengan signifikansi yaitu 0,083 > 0,05 sehingga dapat disimpulkan bahwa $\mathrm{H}_{0}$ diterima dan $\mathrm{H}_{3}$ ditolak yaitu tidak terdapat pengaruh yang signifikan antara produk terhadap minat nasabah menggunakan produk simpanan di BMT Amanah Ummah Gumpang dengan nilai koefisien pengaruh sebesar 0,206.

Berdasarkan hasil penelitian tersebut dapat disimpulkan bahwa variabel produk tidak memiliki pengaruh secara signifikan terhadap minat nasabah menggunakan produk simpanan di BMT Amanah Ummah Gumpang. Pengaruh produk terhadap minat nasabah untuk menggunakan produk simpanan yang tidak signifikan menandakan bahwa nasabah di BMT Amanah Ummah Gumpang hanya sedikit yang menjadikan variabel produk yang sesuai dengan syariah sebagai pengukur atau faktor pendorong minat nasabah untuk menabung di BMT Amanah Ummah Gumpang.

Hal tersebut disebabkan karena sebagian besar nasabah masih awam dengan produkproduk pada lembaga keuangan mikro syariah (BMT) karena mereka belum mengetahui secara detail produk-produk pada lembaga keuangan mikro syariah (BMT) yang sesuai dengan prinsip syariah.

Para nasabah yang minat untuk menggunakan produk simpanan di BMT Amanah Ummah Gumpang sebagian besar tidak menjadikan produk syariah sebagai pengukur atau landasan untuk mendorong minat mereka, namun mereka lebih kepada untuk memenuhi kebutuhan dalam menabung di BMT Amanah Ummah Gumpang tanpa memadang produk tersebut sesuai dengan syariah atau tidak, karena sebagian besar nasabah belum memahami secara detail produk-produk yang ditawarkan di BMT Amanah Ummah Gumpang.

Hasil penelitian ini konsisten dengan penelitian sebelumnya yang dilakukan oleh Chotimah (2014), Pengaruh Produk, Pelayanan, Promosi, dan Lokasi Terhadap Masyarakat Memilih Bank Syariah di Surakarta. Hasil penelitian ini menunjukkan bahwa tidak terdapat pengaruh secara signifikan antara produk dan promosi terhadap masyarakat memilih bank syariah di Surakarta, sedangkan pelayanan dan lokasi terdapat pengaruh secara signifikan terhadap masyarakat memilih bank syariah di Surakarta.

\subsection{Pengaruh religiusitas terhadap minat nasabah.}

Hasil penelitian menunjukkan bahwa terdapat pengaruh yang signifikan antara variabel religiusitas terhadap minat nasabah menggunakan produk simpanan di BMT Amanah Ummah Gumpang dengan signifikansi yaitu $0,039<0,05$ sehingga dapat disimpulkan bahwa $\mathrm{H}_{0}$ ditolak dan $\mathrm{H}_{4}$ diterima yaitu terdapat pengaruh yang signifikan antara religiusitas terhadap minat nasabah menggunakan produk simpanan di BMT Amanah Ummah Gumpang dengan nilai koefisien pengaruh sebesar 0,228 .

Berdasarkan hasil penelitian diatas dapat disimpulkan bahwa apabila tingkat religiusitas seseorang tersebut meningkat atau tinggi maka seseorang tersebut sangat berhati-hati dalam mengambil segala keputusan baik itu dalam mengambil keputusan untuk menjadi nasabah disuatu lembaga keuangan. Hal tersebut sama halnya dengan minat nasabah untuk menggunakan produk simpanan di BMT Amanah Ummah Gumpang,

semakin tinggi religiusitas nasabah di BMT Amanah Ummah Gumpang maka akan semakin tinggi pula minat nasabah untuk menggunakan produk simpanan di BMT Amanah Ummah Gumpang karena sistem yang digunakan di BMT Amanah Ummah Gumpang sesuai dengan prinsip syariah islam. 
Hasil penelitian ini konsisten dengan penelitian sebelumnya yang dilakukan oleh Ningsih (2017), Pengaruh Persepsi, Tingkat Religiusitas, dan Disposable Income Terhadap Minat menabung di Perbankan Syariah (Studi kasus pada dosen UIN Raden Intan Lampung). Hasil penelitian ini menunjukkan bahwa terdapat pengaruh secara signifikan antara persepsi dan tingkat religiusitas terhadap minat menabung di perbankan syariah, sedangkan disposable income tidak terdapat pengaruh secara signifikan terhadap minat menabung di perbankan syariah.

\section{Kesimpulan}

Kesimpulan dari penelitian ini yaitu Pengetahuan berpengaruh secara signifikan terhadap minat nasabah menggunakan produk simpanan pada BMT Amanah Ummah Gumpang Kartasura. Kualitas pelayanan tidak berpengaruh secara signifikan terhadap minat nasabah menggunakan produk simpanan pada BMT Amanah Ummah Gumpang Kartasura. Produk tidak berpengaruh secara signifikan terhadap minat nasabah menggunakan produk simpanan pada BMT Amanah Ummah Gumpang Kartasura. Religiusitas berpengaruh secara signifikan terhadap minat nasabah menggunakan produk simpanan pada BMT Amanah Ummah Gumpang Kartasura. Secara simultan simultan (bersama-sama) antara pengetahuan, kualitas pelayanan, produk, dan religiusitas berpengaruh secara signifikan terhadap minat nasabah menggunakan produk simpanan pada BMT Amanah Ummah Gumpang Kartasura.

\section{Ucapan Terimakasih}

Terimakasih kami haturkan kepada STIE AAS Surakarta atas supportnya hingga selesai dan terbitnya tulisan ini.

\section{Daftar Pustaka}

Algifari, A. R. (2013). Teori, Kasus dan Solusi. Yogyakarta: BPFE.

Anshori, A. G. (2018). Perbankan syariah di Indonesia. UGM PRESS.

Djamaludin, A., \& Suroso, F. N. (2011). Psikologi Islam: Solusi Islam atas Problem- problem Psikologi. Yogyakarta. Pustaka Pelajar.

Gazali, I. (2011). Aplikasi Analisis Multivariate dengan Program IBM SPSS19 Edisi 5. Semarang: Badan Penerbit Universitas Diponegoro.

Hasan, S. A. (2010). Marketing bank syariah: cara jitu meningkatkan pertumbuhan pasar bank syariah. Ghalia Indonesia.

Hidayat, S. (2018). Persepsi Masyarakat Terhadap Baitul Maal Wat Tamwil (Bmt) Dalam Pemberdayaan Ekonomi Masyarakat.alUqud: Journal of Islamic Economics, 2(2), 198-212.

Hurriyati, R. (2010). Bauran pemasaran dan loyalitas konsumen. Bandung: Alfabeta.

Ilmi, M. (2002). Teori dan Praktek Lembaga Mikro Keuangan Syariah. Yogyakarta: UII Pers.

Imran, I., \& Hendrawan, B. (2017). Pengaruh Persepsi Masyarakat Batam Tentang Bank Syariah Terhadap Minat Menggunakan Produk Bank Syariah. journal of applied business administration, 1(2), 63-72.

Kotler, P. (2018). Manajemen Pemasaran edisi 13 jilid 1.

Lubis, A. A. (2018). Analisis Aspek Religiusitas Terhadap Etika Bisnis Pedagang Pasar Muslim Pusat Pasar Kota Medan. Jurnal Dusturiah, 7(1).

Lupiyoadi, R. (2013). Manajemen Pemasaran Jasa. Jakarta: Salemba Empat.

Prassetio, E. (2017). Pengaruh Tingkat Nisbah Bagi Hasil, Penerapan Akad, Citra Merek, Promosi, Dan Kualitas Pelayanan Terhadap Minat Menabung Pada Lembaga Keuangan Perbankan Syariah (Studi Kasus Masyarakat Tangerang Selatan) (Bachelor's thesis, Jakarta: Fakultas Ekonomi dan Bisnis UIN Syarif Hidayatullah Jakarta).

Pratiwi, Muhtadi, A. \& Surahman, E. (2016). Pengaruh Kualitas Pelayanan dan Kepuasan Pelanggan terhadap Niat Beli Ulang (Studi Kasus Pada Depo Farmasi Anggrek RSUD Dr. Hasan Sadikin Bandung. Jurnal Farmasi Klinik Indonesia. Vol. 5. No. 1. 
Putra, A. S., Handoyo, S. S., \& Rochadi, D. (2018). Kualitas Layanan Akademik Mahasiswa di Program Studi Pendidikan Vokasional Konstruksi Bangunan Universitas Negeri Jakarta. Jurnal PenSil, 7(2), 1-8.

Sangadji, E. M. dan Sopiah. (2010). Metodologi Penelitian. Pendekatan Praktis dalam Penelitian. Yogyakarta: Andi.

Santoso, S. (2001) SPSS Statistik Parametrik. PT. Gramedia, Jakarta.

Shaleh, A. R. (2008). Psikologi: Suatu Pengantar dalam Perspektif Islam. Prenada Media.

Sugiyono, (2010). Statistik Untuk Penelitian. Bandung: Alfabeta.

Sukron, S. (2012). Faktor yang Mempengaruhi Minat Nasabah Non Muslim Menjadi Nasabah di Bank BNI Syariah Cabang
Semarang (Doctoral dissertation, IAIN Walisongo).

Susanti, M. D., \& Marita, K. W. (2017). Pengaruh Pengetahuan, Lokasi, Kualitas Pelayanan Dan Bagi Hasil Terhadap Keputusan Anggota Menabung Di Bmt Bina Umat Sejahtera Kalijambe (Doctoral dissertation, IAIN Surakarta).

Taufiq, A. M. (2005). Dinamika Pemasaran: Jelajahi \& Rasakan. Jakarta: PT. Raja Grafindo Persada.

Tjiptono, F. (2000). Strategi Pemasaran. Yogyakarta: Andi Offset.

Yasin, V., Zarlis, M., \& Nasution, M. K. (2018). Filsafat Logika Dan Ontologi Ilmu Komputer. Journal of Information System, Applied, Management, Accounting and Research, 2(2), 68-75. 